\title{
A mulher e a honra no teatro cômico português na segunda metade do século XVIII ${ }^{1}$
}

\author{
Eduardo Teixeira de Carvalho Junior ${ }^{2}$ \\ "Os homens souberam empenhar sua honra e seu \\ nome bem antes de saberem assinar" \\ Marcel Mauss
}

Resumo: Este artigo procura discutir o conceito de honra feminina a partir da análise de alguns textos do teatro cômico português da segunda metade do século XVIII. Com a ampliação dos espaços de sociabilidade, fenômeno associado à popularização dos salões e dos cafés, é possível sugerir uma mudança importante de valores no que se refere à representação dos papéis femininos. Enquanto a dama honrada, tradicional, tinha como ideal o espaço doméstico, a dama moderna deve saber "aparecer" e ser sociável para elevar o prestígio de sua família perante seu círculo de convivialidade.

Palavras-chave: honra feminina, teatro cômico, século XVIII, Portugal.

Abstract: This article discusses the concept of feminine honor based on the analysis of some texts extracted from the Portuguese comic theater of the second half of the 18th century. Considering the expansion of social places, a phenomenon associated with the popularization of lounges and cafes, it is possible to suggest a major shift in values regarding the representation of female roles. While the traditional honored lady lived for the domestic life, the modern lady should know how to behave in society in order to raise the prestige of her family in her circle of conviviality.

Keywords: feminine honor, comic theater, XVIII century, Portugal.

${ }^{1}$ Este texto tem como base o trabalho final proposto para a disciplina do Doutorado História, Imaginário e representações ministrada pelo professor Magnus Roberto de Mello Pereira no segundo semestre do ano de 2013 do PGHIS/UFPR.

2 Eduardo Teixeira de Carvalho Junior possui graduação em História pela Universidade Federal do Paraná (2002), Mestrado em História pela Universidade Federal do Paraná (2005) e doutorado pela Universidade Federal do Paraná (2015). É professor de História e Antropologia nos cursos de Direito e Relações Internacionais da Unicuritiba. Sua principal área de pesquisa é História Moderna e Contemporânea, em especial o tema do Iluminismo em Portugal. É membro do grupo de pesquisa Cultura e Educação na América Portuguesa (GCEAP).

Revista Vernáculo n. ${ }^{\circ} 42$ - segundo semestre/2018

ISSN 2317-4021 
A segunda metade do século XVIII foi um momento de crise e transformação dos padrões de sociabilidade. Com a popularização dos salões, dos cafés e com o aumento da circulação do impresso por meio de jornais e de livros, constitui-se um tipo novo de sociedade marcada pelo signo da modernidade. Nos teatros, diversos costumes e situações do cotidiano passam a ser representados, e geralmente possuíam um duplo papel: ou serviam para deixar uma lição de moral, ao reforçar comportamentos exemplares, ou para criticar e satirizar costumes antigos, considerados fora de moda. Devido à pouca difusão de literatura impressa em Portugal no século XVIII, o teatro e até mesmo a ópera são preciosas fontes históricas para a análise dos padrões de comportamento e sociabilidade do Antigo Regime português. Parte-se da ideia de que o teatro é um sistema de representação social que atua na manutenção de determinadas práticas sociais, assim como na difusão de novos valores e padrões de comportamento. ${ }^{3}$ A partir da seleção e análise de alguns textos deste gênero, a comédia e sobretudo o entremez, este texto procura discutir o conceito de honra e algumas mudanças importantes nos papéis femininos ao longo do século XVIII.

$\mathrm{O}$ entremez foi um modelo teatral cômico que abordava temas do cotidiano de forma crítica e satírica, destacando-se pela forma como eram tratados os conflitos entre os velhos costumes e as novas

3 Cf. CHARTIER, Roger. A História Cultural: entre práticas e representações. Lisboa: DIFEL, 1988; CHARTIER, Roger. A História hoje: dúvidas, desafios, propostas. Estudos Históricos, v. 7, n. 13, 1994.

Revista Vernáculo n. ${ }^{\circ} 42$ - segundo semestre/2018

ISSN 2317-4021 
tendências ditadas pela modernidade. ${ }^{4}$ Enquanto as comédias eram mais longas, geralmente divididas em três atos, os entremezes eram curtos, e costumavam ser encenados nos intervalos de grandes espetáculos. A sua popularização, no final do século XVIII, é um indicativo de mudanças sociais importantes, pois apresentam variações interessantes na maneira como os papéis da mulher passam a ser representados, alterando a percepção da conduta considerada honrosa.

O texto apresenta inicialmente uma discussão teórica sobre o conceito de honra, algumas definições e alguns usos deste conceito em diferentes contextos. Em seguida discute-se a comédia o Cavaleiro e a Dama (1758), utilizada como referência para a identificação do modelo ideal da dama tradicional. Depois são apresentadas algumas mudanças da sociedade portuguesa, cada vez mais perceptíveis a partir da segunda metade do século XVIII, ligadas sobretudo à popularização de novas formas de sociabilidade. Esta tendência explicaria a importância ocupada pela moda em alguns entremezes do final do século XVIII. A análise dos entremezes aponta para uma mudança do modelo ideal da dama tradicional e indicam uma outra percepção do conceito de mulher honrada na sociedade portuguesa do final do século XVIII.

${ }^{4}$ Mais informações sobre entremezes, cf. PETERS, Ana Paula. Nasce toda creatura com sua ventura: o casamento como mote de entremezes para representar a sociedade portuguesa do século XVIII. Curitiba, 2013. Tese (Doutorado em História), 182f. Universidade Federal do Paraná; FONSECA, Elizabeth Pereira Alves da. Versões do "Peralta" no entremez lusitano: o teatro cômico e as representações críticas dos costumes na segunda metade do século XVIII. Curitiba, 2015. (Dissertação de Mestrado em História), 127 f. Universidade Federal do Paraná.

Revista Vernáculo n. ${ }^{\circ} 42$ - segundo semestre/2018

ISSN 2317-4021 


\section{A honra e seu valor social}

Se compreendermos a honra como um conjunto de regras ou costumes que definem comportamentos e papéis preservados em um determinado grupo social, ela está associada ao conservadorismo, à manutenção de padrões de conduta. Conforme exemplifica Julian PittRivers:

Foi exemplar o caso do oficial francês, demitido pelo seu ministro da guerra no começo do século, por ele ter levado à justiça o homem que o havia ofendido, ao invés de chamá-lo para um duelo - em suma, demitido por não ter infringido a lei. Esse respeito à lei civil significa, aos olhos de seu Ministro, uma falta de sentimento de honra. ${ }^{5}$

Mas considerando que a modernidade promove uma mudança rápida de valores e de costumes, poderíamos sugerir então que o conceito de honra vai perdendo a sua efetividade no Ocidente, sobretudo com a emergência do sistema do capitalismo industrial a partir do século XIX. Parafraseando o sociólogo americano Peter Berger, Pitt-Rivers comenta "que aquele que emprega a palavra honra se anuncia como 'hopelessly european' - irremediavelmente do Velho Mundo". ${ }^{6}$ Quando a racionalidade burguesa e suas relações impessoais de mercado não haviam ainda se imposto como um paradigma, a honra ocupava um lugar central nas sociedades europeias. Em seu estudo sobre a história da família, James Casey comenta que, na Europa

${ }^{5}$ Mesmo sendo proibida, a prática dos duelos persistiu até o século XX. Cf. PITTRIVERS, Julian. A doença da honra. In: GAUTHERON, Marie (org.). A honra: imagem de si ou dom de si - um ideal equívoco. Porto Alegre: LP\&M, 1992. p. 20. ${ }^{6}$ PITT-RIVERS, Julian. A doença da honra, p. 17. 
anterior a 1789, a "hierarquia era encarada mais em função da honra do que da riqueza".

Todavia, podemos falar de um esvaziamento do sentimento de honra nos dias de hoje? Com a facilidade e velocidade com que são produzidas e publicadas imagens atualmente, chama a atenção o caso de jovens e adolescentes que praticam suicídio depois de ter suas imagens íntimas publicadas na internet. ${ }^{8}$ Seria um caso de honra? Como se aplicaria o conceito de honra neste caso? A saída para o suicídio pode ser compreendida com a vergonha por terem sua reputação manchada publicamente. Se concordarmos que se trata de uma questão de honra, ela se manifesta como uma imagem de si das adolescentes, perante seu grupo de convívio social, e está associada à reputação e ao prestígio.

Para Norbert Elias, as sociedades de corte do Antigo Regime foram as últimas formações sociais relativamente fechadas em que os homens não trabalhavam e não se preocupavam com uma condução racional de sua economia, sua subsistência dependia de sua capacidade em adquirir prestígio, o que lhe permitiria acesso a uma renda. ${ }^{9}$ Muitos dos valores e das convenções sociais do Antigo Regime, que hoje costumamos identificar com a "etiqueta", perderam seu sentido e sua

${ }^{7}$ CASEY, James. História da Família. Lisboa: Editorial Teorema, 1989, p. 37.

${ }^{8}$ Ver reportagem da revista Época sobre o caso das estudantes Giana Laura, de 16 anos, e Júlia Rebeca, de 17 anos. Ambas se mataram pela mesma razão com apenas quatro dias de diferença sem nunca se conhecerem.

Disponível em:

http://epoca.globo.com/vida/noticia/2013/11/sexo-bchantagem-e-internetb.html

${ }^{9}$ CF. ELIAS, Norbert. A sociedade de corte: investigação sobre a sociologia da realeza e da aristocracia de corte. Rio de Janeiro: Zahar, 2001.

Revista Vernáculo n. ${ }^{\circ} 42$ - segundo semestre/2018

ISSN 2317-4021 
importância para nós. Nessas sociedades, o desconhecimento das regras e das condutas, ou a falta de sua observância, poderia levar o indivíduo a cair em desgraça e até mesmo a ser punido. De acordo com um relato do final do século XVII, a honra ocupava um lugar central na sociedade: "é tudo que existe de mais caro, de mais precioso e de mais sagrado entre os homens". ${ }^{10}$

A honra era um valor social fundamental para a reputação das famílias perante a comunidade, e o equilíbrio do núcleo familiar dependia do cumprimento dos papéis estabelecidos para o homem e para a mulher. Nas sociedades do Antigo Regime sabia-se do poder da maledicência, eram frequentes as queixas por difamação e calúnia:

Neste contexto, qualquer palavra insinuante, provocativa, até mesmo evasiva sobre a reputação de um ou de outro acarreta uma série de consequências imediatas: a dúvida expressa com relação a uma pessoa transforma a corrente de sociabilidade que antes unia numa estima recíproca (ou numa aquiescência) gente que se considerava mais ou menos igual. ${ }^{11}$

Segundo o dicionário de Rafael Bluteau, publicado em Portugal no início do século XVIII, há muitos significados para a palavra honra, porém, para ele, não existe honra verdadeira sem virtude, e de forma geral ela está associada ao "respeito, e reverencia com que tratamos as pessoas em razão de sua nobreza, dignidade,

${ }^{10}$ ARIÈS, Philippe; CHARTIER, Roger. História da vida privada, 3; da Renascença ao século das Luzes. São Paulo: Companhia das Letras, 1991, p. 589.

${ }^{11}$ ARIÈS, Philippe; CHARTIER, Roger. História da vida privada, p. 594. 
virtude, ou outra excelência. Outras vezes é o crédito, e boa fama, seguida com boas ações". ${ }^{12}$

Seguindo a tradição do modelo da família patriarcal, as mulheres, "trancadas" em suas casas, garantiam a legitimidade dos filhos de seu marido. Portanto, a castidade da esposa e sua fidelidade eram uma necessidade social que permitia a reprodução e manutenção do patrimônio da família. A presença feminina, fora do espaço doméstico, poderia significar uma ameaça e um perigo. Em uma sociedade em que a comunidade exerce muita pressão sobre as individualidades, as condutas eram submetidas cotidianamente à aprovação ou reprovação de seus pares. As mulheres sofriam muita pressão pela sua vulnerabilidade, e era muito comum pôr em questão a honra feminina. Em Paris, por exemplo, costumava-se "disseminar dúvidas sobre a virtude das mulheres e até mesmo daquelas às quais nada se poderia reprovar de real nem de aparente em sua conduta". ${ }^{13}$

Portanto, podemos dizer que a honra está ligada ao cumprimento de determinados papéis, de acordo com idade, sexo, classe e ocupação. ${ }^{14}$ De acordo com certa tradição é muito comum a ideia de que do homem espera-se a virtude da coragem, e da mulher, pureza sexual. Talvez essas expectativas estivessem bem consolidadas

12 BLUTEAU, Raphael. Vocabulario Portuguez e Latino. Coimbra: Colégio das Artes, 1712. Volume 4, p. 51. Havia também um outro significado para a noção de honra associado à posse de terras e títulos.

${ }^{13}$ ARIÈS, Philippe; CHARTIER, Roger. História da vida privada, p. 595.

${ }^{14}$ PERISTIANY, J. G. Honra e vergonha: valores das sociedades mediterrânicas. Lisboa: Fundação Calouste Gulbenkian, 1988, p. 28. 
no Antigo Regime, em que a individualidade, em um sentido moderno, não havia ainda se constituído e as pessoas sentiam muito mais as pressões da vigilância da comunidade. Conforme ressalta James Casey: "É tudo muito diferente do mundo industrial, em que a troca de serviços profissionais através dos mecanismos do mercado torna redundante esta rigorosa hierarquização dos papéis". ${ }^{15}$

O século XVIII serviu como um período de transição para o modelo social que se tornaria predominante no século XIX. Havia uma questão de gênero na divisão social das tarefas no Século das Luzes: de forma geral as mulheres deveriam ficar em casa para cuidar do lar e da família, enquanto os homens se ocupavam dos negócios públicos, do governo e do Estado. ${ }^{16}$ Luiz António Verney, um dos primeiros filósofos a defender a ideia de educar as mulheres em Portugal, propõe que elas deveriam ser educadas para atender às demandas específicas do ambiente doméstico: "este é o fim para que a Providência as pôs neste mundo: para ajudarem os maridos ou parentes, empregando-se nas coisas domésticas no mesmo tempo que eles se aplicam às de fora" ${ }^{17}$ Neste contexto social uma mulher poderia assumir diferentes papéis, a solteira, a mulher casada ou viúva, por exemplo, cada uma delas deveria seguir determinadas condutas consideradas adequadas para cada papel específico. Havia os casos de marginalidade, como, por exemplo,

${ }^{15}$ CASEY, James. História da Família. Lisboa: Editorial Teorema, 1989, p. 192.

${ }^{16}$ DUBY, Georges; PERROT, Michele. História das mulheres no Ocidente. Porto: Edições Afrontamento, 1991, v. 3, p. 389.

${ }^{17}$ VERNEY, Luis Antonio. Verdadeiro Método de Estudar. Lisboa: Livraria Sá da Costa - Editora, 1950, v. 5, p. 137.

Revista Vernáculo n. ${ }^{\circ} 42$ - segundo semestre/2018

ISSN $2317-4021$ 
quando a mulher exercia o papel desonroso de uma prostituta. ${ }^{18}$ Esses papéis costumavam ser reforçados por meio de suas representações nos teatros de costumes.

\section{A mulher e a honra: o caso de D. Leonor}

Na comédia O Cavaleiro e a Dama (1768) é apresentado o caso de D. Leonor, que possui todas as qualidades de uma dama honrada: casta, submissa, recatada, modesta e trabalhadora. ${ }^{19}$ Vivia em uma das casas mais ricas da cidade, até que seu marido, D. Roberto, é desterrado por ter matado um "injusto Ministro" que o havia afrontado. As rendas da família são confiscadas, ficando D. Leonor pobre e sem recursos. Porém, D. Leonor, para manter a honra de sua família, trabalhava dia e noite como costureira para garantir algum sustento e administrar a casa que sofria com a falta de recursos.

Além disso, D. Leonor parecia ser uma mulher bonita para os padrões da época. Alguns cavaleiros como D. Rodrigo, amigo da família, e Anselmo, o mercante, costumavam cortejá-la e sempre ofereciam ajuda financeira, o que indica que seus sentimentos iam além de mera compaixão por uma dama desamparada. Entretanto, D. Leonor,

${ }^{18}$ DUBY, Georges; PERROT, Michele. História das mulheres no Ocidente, p. 349.

19 Geralmente a dama podia frequentar mais os ambientes públicos por ter à disposição criados que a auxiliavam nas tarefas domésticas. Vale ressaltar que a figura dos criados é muito frequente nos entremezes e comédias portugueses. Conforme aponta José Cutileiro, "a mulher pobre tem mais dificuldade em furtar-se a tentações: trabalha muitas vezes com homens no campo, encontra-os nas vendas..." PERISTIANY, J. G. Honra e vergonha: valores das sociedades mediterrânicas. Lisboa: Fundação Calouste Gulbenkian, 1988, p. XX. 
resignada, esquivava-se e recusava-se a receber o dinheiro, por considerar esta conduta desonrosa, mesmo com as reclamações de sua criada, que, alegando passar fome, a incentivava a aceitar. D. Leonor chega a penhorar alguns bens para poder ajudar seu marido, que havia solicitado auxílio no desterro. Sua atitude era exemplar, pois indicava sua capacidade em administrar a economia doméstica, que naquele momento passava por uma crise. Quando sua situação se complicava muito, acabava aceitando as ofertas de ajuda, mas em sigilo, e sempre deixava evidente que se tratava de dívida a ser paga no futuro.

Todavia, a forma honrosa como D. Leonor sobrevivia à sua condição seria colocada à prova por D. Flaminio, que a acusa de ser amante de D. Rodrigo e de estar sendo sustentada por ele, em troca de afetos. Anselmo rebate a acusação e afirma não tolerar murmurações "contra uma senhora tão honrada". Entretanto, para provar sua tese, D. Flaminio aposta um relógio de ouro que iria até a casa de D. Leonor e, com "poucos cumprimentos", ela se tornaria sua amante e passaria a desprezar D. Rodrigo. A aposta, então, é aceita por um outro cavaleiro que presenciava a conversação.

D. Flaminio era um tipo de cavaleiro que havia perdido a honra; era mentiroso e desonesto, e acabava causando uma série de intrigas no círculo de convívio social de D. Leonor. Para tentar se aproximar dela e ganhar a aposta, mente que estava em contato com seu marido. D. Leonor, por estar carente de notícias, acaba concordando em encontrá-lo. Em uma das conversações, para chamar a atenção de D. 
Leonor, diz que tinha notícias recentes de seu marido. Porém, acaba sendo desmentido publicamente por D. Rodrigo, que anuncia a morte de D. Roberto por meio de uma carta oficial. Assim, a pobre D. Leonor havia se tornado viúva. D. Flaminio, ao ser desmentido publicamente, considerando-se ofendido, envia um bilhete pelo seu criado intimando a D. Rodrigo para um duelo de espada. D. Rodrigo responde ao desafio informando que não aceitaria, justificando que tal prática era proibida.

Com a notícia da morte de D. Roberto, D. Rodrigo resolve confessar que a amava, mesmo quando ela ainda estava casada; um segredo infeliz, "porém honrado", que "sepultado guardava, por decência de respeito". D. Leonor também abre seu coração e confessa que o sentimento era recíproco. Porém, mesmo com a morte de D. Roberto e seu estado civil alterado na condição de viúva, ambos declaram que o amor que sentiam um pelo outro era desrespeitoso, um amor sem honra. D. Rodrigo pondera que, ao invés de ceder aos instintos do coração, optaria por um caminho honrado: "de projeto se mude, triunfe a honra, exalte-se a virtude". ${ }^{20}$ Como castigo pelo sentimento desonroso que nutria por D. Leonor, resolve aplicar a si mesmo o remédio do autodegredo, ou seja, retirar-se e sair "vagando sozinho pelo mundo". Já D. Leonor resolve ocultar aquele sentimento desonroso "entre os sagrados votos da clausura".

${ }^{20}$ O Cavaleiro e a Dama, p. 41.

Revista Vernáculo n. ${ }^{\circ} 42$ - segundo semestre/2018

ISSN 2317-4021 


\section{Conter paixões de amor, é virtude, honra e prudência}

Em Portugal, a prática do luto imposta às viúvas era bastante severa; somente pelo alvará de 1761 determinou-se para no máximo um mês o encerro em casa. ${ }^{21}$ Também era muito comum a prática do recolhimento (conventos), que servia tanto para punir os desvios de comportamento feminino quanto para amparar as mulheres que, pela morte do pai ou do marido, ou pela degradação econômica de seu lar, haviam perdido o amparo da família:

Mulheres solteiras ou viúvas que põem em perigo a honra, ou mais provavelmente os interesses da família, eram depositadas contra sua vontade por ordem do chefe do agregado familiar. Mulheres casadas eram também recolhidas a mando do marido que podia invocar ameaça da sua honra, medida de segurança durante a sua ausência, adultério consumado. O depósito podia ser aceite e até desejado pela mulher, ou, pelo contrário, envolver situações dramáticas de recolhimento compulsivo de uma irmã, uma filha, uma mãe, uma sogra ou uma esposa e de uma cruel e definitiva separação dos filhos e outros familiares. ${ }^{22}$

O que a história de D. Leonor e D. Rodrigo parece querer ensinar é que os sentimentos de amor deveriam ser sacrificados para dar lugar aos valores morais, de acordo com o papel ocupado pelo

${ }^{21}$ Cf. LOPES, Maria Antónia. Mulheres, espaço e sociabilidade. Lisboa: Estampa, p. 136.

${ }^{22}$ LOPES, Maria Antónia. Do outro lado da festa: a inflexível piedade barroca num recolhimento de Coimbra (O Recolhimento do Paço do Conde durante o século XVIII). Atas do IV Congresso Internacional do Barroco Íbero-Americano. Universidade de Coimbra, 2008. Disponível em: $<$ https://estudogeral.sib.uc.pt/bitstream/10316/24029/1/Do\%20outro\%20lado\%20da\% 20festa.pdf >. Acesso em: 30 jul. 2018.

Revista Vernáculo n. ${ }^{\circ} 42$ - segundo semestre/2018

ISSN 2317-4021 
indivíduo na sociedade. Conforme afirmava D. Rodrigo, por ser uma dama honrada, D. Leonor não conseguiria deixar que o amor por ele fluísse diante de murmurações (fofocas), que existiam no meio social em que viviam. Assim, para evitar a "maledicência" e manter a honra, ambos assumem tal martírio. Porém, enquanto alguns personagens afirmavam que D. Rodrigo e D. Leonor eram heróis, e modelo a ser seguido pelos demais, outros, ao contrário, defendiam que eram tolos por exagerarem na autopunição. A tensão entre o tradicional e $o$ moderno é assim exacerbada, o que dá o tom satírico da comédia.

No desfecho da comédia, o exemplo de D. Leonor ainda receberia mais um reforço. Premiados por suas atitudes exemplares, o "destino" cria uma situação favorável para que os sentimentos amorosos do casal pudessem triunfar de forma legítima. Inesperadamente, surge uma correspondência do falecido marido contendo seus últimos suspiros. A carta continha tudo o que na hora extrema pronunciou D. Roberto aos que lhe assistiam:

Querido amigo, que tendes a bondade de assistir-me nestes últimos instantes da minha vida: recomendo-vos a cousa mais estimada, que tenho no mundo, que é a minha infeliz consorte; ela fica pobre, e desamparada, sem renda alguma: esta é a maior de minhas aflições. D. Rodrigo Raspani, que é o cavaleiro mais honrado, que eu tenho conhecido, sempre se mostrou meu amigo, e favorável para minha casa: pedi lhe encarecidamente em meu nome, ou por cartas, ou por algum vosso amigo, que por caridade não desampare a minha infeliz consorte. Isto 
espero na providencia do céu, a quem encomendo esta pobre, e honradíssima senhora. ${ }^{23}$

Diante dessa situação, a posição de D. Rodrigo se altera, já que não se casaria por amor, mas por compaixão, conforme sugeriam os amigos:

Mostrai-vos menos severo nas máximas, e inteirezas de uma virtude, que pode ser rigorosa e violenta. Bem pública é sua honrada modéstia, D. Rodrigo, recebei senhor a esposa por amor do céu. ${ }^{24}$

Até mesmo Anselmo - que costumava emprestar dinheiro a D. Leonor, e demonstrava nutrir sentimentos que iam além de uma mera admiração pela dama virtuosa - oferece uma quantia em dinheiro que serviria de dote para o casamento. Depois de relutar, D. Rodrigo aceita a ideia do matrimônio considerando que não haveria "maledicência".

Porém, mesmo depois dos elogios e aplausos do público, o casal segue o protocolo tradicional e passa a discutir as condições do luto. D. Leonor estabelece o período de um ano, enquanto as amigas, considerando um exagero, propõem um tempo mais curto de seis ou três meses de luto. ${ }^{25}$ Por fim, decide-se pela solução mais honrosa e tradicional: D. Leonor ficaria um ano em estado de clausura em um convento, enquanto D. Rodrigo exaltaria a virtude da paciência.

${ }^{23}$ O Cavaleiro e a Dama, p. 44-45.

${ }^{24}$ Ibid., p. 45.

${ }^{25}$ O Cavaleiro e a Dama, p. 46.

Revista Vernáculo n. ${ }^{\circ} 42$ - segundo semestre/2018

ISSN 2317-4021 
O preço pago por ambos nesta comédia é exagerado, mas segue a conduta exemplar do cavaleiro e da dama honrados. Embora criticados por alguns personagens, a maioria acaba aplaudindo a decisão do casal e no final todos concluem: "que conter paixões de amor, é virtude, honra e prudência". ${ }^{26}$

\section{A moda e os novos papéis femininos no final do Antigo Regime}

$\mathrm{Na}$ medida em que novas práticas sociais passam a ser popularizadas e representadas como modelo de uma sociedade moderna e civilizada, outros modelos e papéis sociais vão surgindo e passando a colocar em questão o que até então era considerado como uma conduta exemplar. As comédias populares cumpriam uma importante função moral na preservação de determinados papéis considerados fundamentais, com o objetivo de manter o equilíbrio social. ${ }^{27} \mathrm{Em}$ Portugal, antes de serem publicados, os textos de teatro eram submetidos à censura da Real Mesa Censória, criada pelo Marquês de Pombal em 1768. Sabemos que no século XVIII as fronteiras entre o público e o privado ainda não estavam nitidamente estabelecidas, como se consolidaria no século XIX, em que passa a existir uma população anônima de pessoas que já não se conhecem, em que o trabalho e o convívio com a família são atividades separadas. Para Rousseau, o estilo de vida das grandes cidades como Paris e Londres corrompia os

${ }^{26} \mathrm{Id}$.

${ }^{27}$ Cf. MONTEIRO, Nuno Gonçalo. História da vida privada em Portugal: a idade moderna. Lisboa: Círculo dos Leitores, 2010, p. 150.

Revista Vernáculo n. ${ }^{\circ} 42$ - segundo semestre/2018

ISSN 2317-4021 
costumes, pois se cultivavam prazeres que não contribuíam para procriar e manter a vida. Conforme aponta Sennett, a sociabilidade é fruto do lazer; num estado de lazer as pessoas interagem pelo simples prazer do contato. $^{28}$ Quanto mais interagem fora dos rigores da necessidade, mais os homens se tornarão atores. Por isso, a cidade grande é um teatro; ao representar uma vida pública, os homens perdem contato com a virtude moral, pois as pessoas se comportavam como atores de forma a serem sociáveis.

Nesse conjunto de mudanças, Philippe Ariès aponta para o surgimento de grupos de convivialidade nos meios que não pertenciam à corte e estavam acima das classes populares. ${ }^{29} \mathrm{Em}$ Portugal, por exemplo, nas chamadas assembleias ${ }^{30}$, homens e mulheres se encontravam para conversar e se divertir. Emergia uma cultura de pequenas sociedades e de clubes dedicados à conversação, ou ao que ele denomina de "jogos de sociedade: jogar, cantar, tocar música, discutir, ler, comentar leituras". ${ }^{31}$ Nesse momento de transição, o problema é compreender a passagem de um tipo de sociabilidade "em que o privado e o público se confundem para uma sociabilidade na qual o privado é separado do público". ${ }^{32}$ A progressiva separação da esfera privada em

${ }^{28}$ Cf. SENNETT, Richard. O declínio do homem público: as tiranias da intimidade. São Paulo: Companhia das Letras, 1988.

${ }^{29}$ ARIÈS, Philippe; CHARTIER, Roger. História da vida privada, p. 15.

${ }^{30}$ Assembleia designa a forma portuguesa do salão. Cf. MONTEIRO, Nuno Gonçalo. História da vida privada em Portugal: a idade moderna. Lisboa: Círculo dos Leitores, 2010, p. 445.

${ }^{31}$ Id.

${ }^{32}$ ARIÈS, Philippe; CHARTIER, Roger. História da vida privada, p. 16. 
contraposição ao espaço público levaria a uma valorização da individualidade, ampliando a liberdade em relação aos constrangimentos comunitários. ${ }^{33}$ No bojo dessas mudanças, os papéis femininos passaram por transformações importantes.

Conforme já havíamos apontado anteriormente, a "pretensa inferioridade intelectual" feminina seria questionada pelo iluminista português Luiz António Verney, que argumentava que, se os homens preferiam levar uma vida boêmia, longe de suas famílias, a culpa era das mulheres que, por serem incapazes de levar uma boa conversa, não sabiam "adoçar o ânimo agreste de um marido áspero e ignorante" ou "entreter melhor a disposição de ânimo de um marido erudito". ${ }^{34}$ Saber conversar e tornar o convívio doméstico mais interessante demandaria desenvolver qualidades e habilidades que a maior parte das mulheres não possuía, ou eram interpretadas como comportamentos suspeitos para uma mulher dedicada ao lar e à família. A ideia de Verney acabaria abrindo um caminho para as mulheres na direção do espaço público, tornando-as aptas ao convívio social.

Com a expansão dos espaços públicos, por meio da popularização dos salões e das assembleias, cada vez mais as mulheres assumiriam novos papéis, na medida em que ocorria uma reformulação das fronteiras entre o espaço doméstico e as novas formas de sociabilidades, que se tornavam cada vez mais recorrentes. A própria

${ }^{33}$ Cf. MONTEIRO, Nuno Gonçalo. História da vida privada em Portugal: a idade moderna. Lisboa: Círculo dos Leitores, 2010, p. 160.

${ }^{34}$ VERNEY, Luis Antonio. Verdadeiro Método de Estudar. Lisboa: Livraria Sá da Costa, 1950, v. 5,p. 126. 
estrutura das habitações passou a ser projetada e adaptada de acordo com as mudanças sociais vigentes, resguardando o ambiente da intimidade da família dos espaços da casa reservados para receber convidados. $^{35}$ Como lembra Habermas, a grande novidade na arquitetura das mansões burguesas é o espaço ocupado pelo salão, que serve à sociedade, e não ao círculo restrito dos amigos da família. ${ }^{36}$

A natureza 'pública' do salão de convivência da grande família, em que a dona da casa, ao lado do senhor da casa, representava perante a criadagem e a vizinhança, dá lugar à sala de estar da pequena-família, em que a esposa, com seus infantes, separa-se da criadagem. Festas familiares tornam-se noitadas em sociedade, a sala da família tornase sala de recepção, em que as pessoas privadas se reúnem num público (...) A linha entre a esfera privada e a esfera pública passa pelo meio da casa. As pessoas privadas saem da intimidade de seus quartos de dormir para a publicidade do salão: mas uma está estreitamente ligada à outra. ${ }^{37}$

A popularização do hábito de se reunir em assembleias exigia cada vez mais que as mulheres desenvolvessem outras habilidades, como saber conversar, dançar, vestir-se de acordo com a moda e, eventualmente, tocar algum instrumento, o que implicava um novo papel a ser exercido por elas.

A valorização da moda faz surgir novos tipos sociais como as bandarras, que se preocupavam excessivamente com os trajes e cortes de cabelo, e a grifaria, representada geralmente por aqueles que

${ }^{35}$ Cf. ELIAS, Norbert. A sociedade de corte; CASEY, James. História da família.

${ }^{36}$ HABERMAS, Jürgen. Mudança estrutural da esfera pública, p. 62.

${ }^{37} \mathrm{Id}$.

Revista Vernáculo n. ${ }^{\circ} 42$ - segundo semestre/2018

ISSN 2317-4021 
estavam fora de moda e que procuravam preservar antigos costumes. No ambiente de corte português, na primeira metade do século XVIII já havia o hábito de organizar saraus musicais, porém essa prática ficava restrita à fidalguia. ${ }^{38}$ A partir do início do período pombalino a nobreza passou a conviver com outros estratos sociais e, mais especificamente a partir da década de 1760, observa-se uma diminuição do número de ingressos no clero, apontando para uma crise de valorização social das carreiras eclesiásticas nas elites portuguesas. ${ }^{39}$

\section{O entremez e a liberdade feminina: corrupção dos novos tempos?}

As tensões entre o antigo e o moderno vão se tornando cada vez mais evidentes à medida que nos aproximamos do final do século XVIII. A partir da década de 1780 observamos um aumento significativo da publicação de peças de teatro, principalmente $o$ entremez, que em Portugal teve grande repercussão. A sua popularização, no final do século XVIII, é um indicativo de mudanças sociais importantes, sobretudo em relação aos valores familiares, com destaque para os papéis do homem e da mulher. Por exemplo, na comédia intitulada Assemblea (1782), Rosaura, à procura de uma nova criada, comenta com uma candidata que não reparava tanto nos

${ }^{38}$ MONTEIRO, Nuno Gonçalo. História da vida privada em Portugal, p. 447.

${ }^{39}$ MONTEIRO, Nuno Gonçalo. História da vida privada em Portugal, p. 147. Vale lembrar os estudos de Michel Vovelle sobre o clima de dessacralização da sociedade francesa, a partir da segunda metade do XVIII, como elemento central para se compreender a sensibilidade pré-revolucionária. Cf. VOVELLE, Michel. Ideologias e mentalidades. São Paulo: Brasiliense, 1987. 
descuidos com os afazeres mais simples, como varrer e limpar, mas exigia que suas criadas soubessem pentear de acordo com a moda. ${ }^{40}$ Neste exemplo, a responsabilidade pelo bom funcionamento do espaço doméstico, como argumentava Verney, dá lugar às novas exigências da moda, uma preocupação típica do ambiente público.

No entremez Amor sem pés nem cabeça (1789), Merlim, o criado, reclama com Armelindo, seu senhor, sobre o estranho comportamento de algumas mulheres: "O mundo está perdido; a peraltice, com que estas madamas se apresentão em público, é de admirar; não tem vergonha alguma que as critiquem..." ${ }^{41}$. Eles discutem o caso de uma casa em que o "chefe dominador" era a mulher, que "governava", "gritava quando era seu gosto", "despedia criados", e o bom homem do marido não dava nenhuma palavra, era conhecido por "Manuel Marica". Ambos discutem sobre uma suposta crise dos novos tempos, em que os homens estavam "abandonando o barco":

Se um piloto, ou por pouca ciência, ou por descuido deixa perder o rumo, e então vê a total ruina da embarcação, que lhe fora imcumbida; da mesma sorte o Pai de famílias, esquecendo-se do equilíbrio em que deve ter a paz, e o comportamento de sua casa, a perde, e totalmente a destroe. $^{42}$

${ }^{40}$ Nova Comedia de um Engenho Português denominada Assemblea. Lisboa: Na oficina de Francisco Borges de Sousa, 1782.

${ }^{41}$ Novo, e Gracioso Entremez Intitulado Amor Sem Pés Nem Cabeça. Lisboa: Oficina de Francisco Borges de Sousa, 1789, p. 4.

${ }^{42}$ Id. 
Por outro lado, o criado Bacello, no entremez Casamento por nova idéia (1792), adverte Denguice, sua pretendente, que, depois de casada com ele, ela deveria abandonar a moda e seguir o modelo de mulher honesta, com "cabelo razo", sem "tupete acarapinhado", sem enfeites e ser "sizuda", "modesta" e "grave". ${ }^{43}$ A criada Denguice não aceitava a imposição do modelo tradicional e reclamava: "pois queres que deixe as modas? Para o mundo dizer, que vivo aborrecida do mundo?". ${ }^{4}$ No final, ela acaba cedendo às exigências de seu pretendente, porém, à parte, pondera: "que remédio tenho eu, senão estar pelo que ele quer, depois farei o que me parecer". Assim, Denguice consegue garantir seu casamento sem abrir mão totalmente da moda. Este entremez pode sugerir que os criados passaram a ter mais liberdade e autonomia, ou que Denguice, mesmo na condição de criada, passa a ter certa liberdade de ação para "driblar" a estrutura patriarcal dominante por meio de estratégias individuais.

No final do século XVIII, acompanhados pela perspectiva da moda, os costumes se modificam, e alguns entremezes apontam como é honroso, para o marido, ter uma mulher que saiba se comportar nas assembleias, conversar, dançar e se divertir, pois os maridos querem evitar serem ridicularizados e chamados de grifo. $^{45}$ No entremez

${ }^{43}$ Novo, e divertido entremez intitulado casamento por nova ideia. Lisboa: Oficina de Francisco Borges de Sousa, p. 12.

${ }^{44}$ Ibid., p. 11.

${ }^{45}$ Grifo era aquele indivíduo que vivia fora da moda.

Revista Vernáculo n. ${ }^{\circ} 42$ - segundo semestre/2018

ISSN 2317-4021 
Casquilharia por força $(1781)^{46}$, o pai de um casal de jovens portugueses que andavam na moda, reclamava dos filhos que só se ocupavam em cantar e dançar, enquanto ele só trabalhava "suando gotas" para sustentá-los. ${ }^{47}$ Ele exaltava um outro tempo em que a educação era voltada para "outra casta de propósitos e respeito". ${ }^{48} \mathrm{O}$ filho responde ao pai que os antigos "não tinham bom gosto, nem sabiam entrar na sociedade, como os modernos", e a filha argumenta que o pai, ao invés de reclamar, deveria valorizar o esforço dos filhos que representavam e estimavam a honra do pai, por serem "capazes de aparecer". ${ }^{49}$ Saber aparecer se tornava cada vez mais um valor social importante.

No entremez A defesa das madamas a favor das suas modas (1792), Theobaldo é um velho chefe de família que defende a moda a favor das mulheres e satiriza a moda seguida por alguns homens, chamando-os de bandalhos:

segui as modas; mas em todas fui moderado: nada disto vejo agora: apresenta-se um bandalho com um redondo chapéu, com sua fivela, e laço, dois anéis sobre as orelhas, que podem servir de trancas para as portas de uma cidade... umas meias salpicadas, qual a pele de onça, ou tigre horrendas, feias sem gosto... e tem estes

${ }^{46}$ Novo entremez intitulado, Casquilharia por força. Lisboa: Oficina de Domingos Gonçalves, 1781.

${ }^{47}$ Ibid., p. 2.

${ }^{48}$ Id.

${ }^{49}$ Novo entremez intitulado, Casquilharia por força, p. 2.

Revista Vernáculo n. ${ }^{\circ} 42$ - segundo semestre/2018

ISSN 2317-4021 
bandalhos a confiança de criticarem as modas que as pobres mulheres usão! ${ }^{50}$

O pai, para provar seus argumentos, resolve promover uma assembleia para debater as polêmicas sobre a moda. Theobaldo se coloca como o juiz da contenda, suas duas filhas, Laureta e Cassimira, defenderiam a moda a favor das mulheres, e seus dois namorados, Petimetre e Franxinote, seriam os opositores e críticos da moda feminina. Franxinote, alegando usar da razão em seu discurso, argumenta que a moda feminina estava levando as famílias à ruína e à decadência:

É verdade que abundam as criticas contra as Madames, e também é verdade que todas são justíssimas; elas tem sido a ruína, e o estrago de imensas famílias: o luxo tem pervertido a ordem das sociedades, pobres pais, que com seus medíocres lucros a penas podião manter-se no regaço da paz sem dívidas, eu os vejo pobres, empenhados, e talvez faltos de crédito para cevarem o gosto de suas filhas, e mulheres com as modas que de dia, em dia se inovão, e se descobrem: e que modas são estas? Seja-me permitido esta expressão: ridicularias que já mais se podem ver sem rizo, e sem escarneo. ${ }^{51}$

Laureta argumentava a favor das mulheres:

O nosso sexo abraça estes enfeites bem como nascidos para seu uso, nós os seguimos, e sobre estes primeiros inventos multiplicamos ideias, e ai ao que v.m chama de excesso quando o não é; mas sim uma precisão infalível

${ }^{50}$ A defesa das madamas a favor das suas modas, p. 2.

${ }^{51}$ Ibid., p. 8. 
para figurarmos no mundo, e hombrear mos sem nota a face das nossas semelhantes. ${ }^{52}$

Theobaldo, no papel do velho chefe de família, exalta o dinheiro gasto na educação de suas filhas e as declara vencedoras na disputa intelectual com seus pretendentes. A história termina com final feliz: o pai anuncia publicamente a autorização para o casamento de suas filhas, e no final um dos criados conclui com o ensinamento da peça: "concluímos uma empresa de muita gloria a de defendermos os enfeites das senhoras, contra quem a maledicencia se tem empenhado com a espada das mais temíveis sátiras" ${ }^{\$ 3}$. O criado termina fazendo uma alusão à popularização de comédias e entremezes que satirizavam a moda, concluindo que a lição deste entremez cumpria justamente a função de criticá-los.

\section{Considerações finais}

Na comédia o Cavaleiro e a Dama, publicada no período pombalino (1750-1777), observamos a intenção de se reforçar o papel da mulher doméstica, fiel, recatada, discreta e voltada para a administração da casa, mas que, mesmo na ausência do marido, sabia manter o status da família nas assembleias. Algumas décadas mais tarde, nos entremezes do período pós-pombalino, percebemos uma tensão entre o papel tradicional da mulher doméstica com a mulher moderna, que passa a ser valorizada por saber transitar nos espaços

52 Id.

${ }^{53} \mathrm{~A}$ defesa das damas a favor das suas modas, p. 13.

Revista Vernáculo n. ${ }^{\circ} 42$ - segundo semestre/2018

ISSN 2317-4021 
públicos com desenvoltura, de acordo com os padrões modernos da "civilização europeia".

Em um corpus documental constituído por aproximadamente 50 textos de teatro consultados nesta pesquisa, a comédia O Cavaleiro e a Dama é a mais antiga: data do período de Pombal (1768), porém com as licenças do Santo Ofício datadas de 1764, o que pode justificar o seu caráter mais conservador. A maior parte do material analisado tem data posterior a 1780, em sua maioria de entremezes, e observamos uma crítica social às mulheres que convivem em espaços públicos. Essas críticas indicam uma maior presença das mulheres frequentando esses espaços, tendência que parece estar associada às novas formas de sociabilidade portuguesas, com popularização das assembleias, tema bastante recorrente nos documentos consultados. Tendo como referência os textos analisados, é possível sugerir uma mudança importante de valores, no que se refere à representação dos papéis femininos, na medida em que se passa a valorizar a mulher que sabe se comportar e se sociabilizar na ocasião desses eventos sociais, tendência que se acentua à medida que nos aproximamos do final do século XVIII.

Assim, à medida que os valores da sociedade vão se alterando, modificando os padrões de conduta, também se transforma a percepção dos comportamentos considerados honrosos. Os entremezes parecem apontar uma tendência que se acentua no final do Antigo Regime; Lopes indica que é a partir dos anos 70 do século XVIII que ocorrerá 
uma vulgarização das novas formas de sociabilidade, em que participam homens e mulheres, principalmente nas assembleias. ${ }^{54} \mathrm{~A}$ mulher que sabia aparecer, vestir-se de acordo com a moda, dançar e conversar em público, elevava o prestígio de sua família perante seu círculo de convivialidade. A dama honrada, tradicional, que tem como ideal o espaço doméstico, passa a competir com a dama moderna, que sabe aparecer e ser sociável.

Mas realmente estariam ocorrendo mudanças sociais, conforme parecem estar representadas nos entremezes, ou seria apenas um recurso dramático do gênero satírico, com a intenção de produzir o riso?

Sabemos que a comédia e a sátira definem-se pela possibilidade de criar situações atípicas e inusitadas do cotidiano, como as inversões de papéis entre homens e mulheres. Mas, conforme ressalta Chartier, não podemos considerá-las como neutras e sem relação com a realidade:

Embora aspirem à universalidade de um diagnóstico fundado na razão, as representações do mundo social assim construídas, são sempre determinadas pelos interesses de grupo que os forjam, não são de forma alguma discursos neutros. Estão sempre imersos em um campo de concorrências e de competições cujos desafios se enunciam em termos de poder e de dominação... Estes acabam por descrever a sociedade tal como pensam que ela é, ou como gostariam que fosse. ${ }^{55}$

${ }^{54}$ LOPES, Maria Antónia. Mulheres, espaço e sociabilidade. Lisboa: Estampa, 1989, p. 109.

${ }^{55}$ CHARTIER, Roger. A História Cultural: entre práticas e representações. Lisboa: DIFEL, 1988, p. 17-19. 
Portanto, o teatro, como uma forma de representação social, é fruto de uma negociação e de um conflito em torno de um projeto ideológico. Devemos ainda considerar que, além de servir como uma forma de crítica aos costumes, o teatro pode até mesmo induzir comportamentos que não ocorreriam na realidade se não fossem representados no mundo fictício das comédias e dos entremezes.

\section{Referências:}

ARIÈS, Philippe; CHARTIER, Roger. História da vida privada. v. 3 : da Renascença ao século das Luzes. São Paulo : Companhia das Letras, 1991.

CASEY, James. História da Família. Lisboa: Editorial Teorema, 1989.

CHARTIER, Roger. A História Cultural: entre práticas e representações. Lisboa: DIFEL, 1988.

DUBY, Georges; PERROT, Michele. História das mulheres no Ocidente. v. 3. Porto: Edições Afrontamento, 1991.

ELIAS, Norbert. A sociedade de corte: investigação sobre a sociologia da realeza e da aristocracia de corte. Rio de Janeiro: Zahar, 2001.

FONSECA, Elizabeth Pereira Alves da. O casamento segundo o teatro de cordel em Portugal (1783-1794). Monografia. Curitiba, UFPR, 2011.

HABERMAS, Jürgen. Mudança estrutural da esfera pública: investigações quanto a uma categoria da sociedade burguesa. Rio de Janeiro: Tempo Brasileiro, 2003.

LOPES, Maria Antónia. Mulheres, espaço e sociabilidade: a transformação dos papéis femininos em Portugal à luz de fontes 
literárias (segunda metade do século XVIII). Lisboa: Livros Horizonte, 1989.

LOPES, Maria Antónia. Mulheres, espaço e sociabilidade. Lisboa: Estampa, 1989.

LOPES, Maria Antónia. Do outro lado da festa: a inflexível piedade barroca num recolhimento de Coimbra (O Recolhimento do Paço do Conde durante o século XVIII). Atas do IV Congresso Internacional do Barroco Íbero-Americano. Universidade de Coimbra, 2008. Disponível em:

<https://estudogeral.sib.uc.pt/bitstream/10316/24029/1/Do\%20outro\%2 0lado\%20da\%20festa.pdf $>$. Acesso em: 30 jul. 2018.

MONTEIRO, Nuno Gonçalo. História da vida privada em Portugal: a idade moderna. Lisboa: Círculo dos Leitores, 2010.

PITT-RIVERS, Julian. A doença da honra. In: GAUTHERON, Marie (org.). A honra: imagem de si ou dom de si - um ideal equívoco. Porto Alegre: LP\&M, 1992.

PERISTIANY, J. G. Honra e vergonha: valores das sociedades mediterrânicas. Lisboa : Fundação Calouste Gulbenkian, 1988.

SENNETT, Richard. O declínio do homem público: as tiranias da intimidade. São Paulo: Companhia das Letras, 1988.

\section{Fontes}

BLUTEAU, Raphael. Vocabulario Portuguez e Latino. Volume 4. Coimbra: Colégio das Artes, 1712.

Graciosa, e divertida farça ou o novo entremez intitulado a defesa das madamas a favor das modas, em que deixão convencida a peraltisse dos homens. Lisboa: Na oficina de Antonio Gomes, 1792. 
Comédia Nova, segundo o gosto do theatro português intitulada: o cavaleiro e a dama. Lisboa: Oficina de Francisco Borges de Sousa, 1768.

Nova Comedia de um Engenho Português denominada Assemblea. Lisboa: Na oficina de Francisco Borges de Sousa, 1782.

Novo, e Gracioso Entremez Intiltulado Amor Sem Pés Nem Cabeça. Lisboa: Oficina de Francisco Borges de Sousa, 1789.

Novo, e divertido entremez intitulado casamento por nova ideia. Lisboa: Oficina de Francisco Borges de Sousa.

Novo entremez intitulado, Casquilharia por força. Lisboa: Oficina de Domingos Gonçalves, 1781.

VERNEY, Luis Antonio. Verdadeiro Método de Estudar. v. 5. Lisboa: Livraria Sá da Costa, 1950.

Recebido em 19/05/2017, aceito para publicação em 02/09/2017 